\title{
KETENTUAN HUKUM TENTANG USIA CALON PESERTA DIDIK PENDIDIKAN DASAR BERDASARKAN SISTEM PENDIDIKAN NASIONAL DI INDONESIA (STUDI KASUS DI DAERAH KOTA DENPASAR)
}

\author{
Oleh: \\ Made Suksma Prijandhini Devi Salain ${ }^{1}$
}

\begin{abstract}
Primary education is a first level education in Indonesia which has mandatory characteristic based on national education system. National education system is presupposing every citizens that 7 (seven) years old until 15 (fifteen) years old are obligatory to enroll the primary education. This statement is making confusion in determining the age limit for the students in Indonesia primary education. For example, public and private elementary schools in Denpasar determining different requirements of age limit for their students. Public elementary schools are presupposing their candidate students for minimum 7 (seven) years old whereas private elementary schools are more flexible in specifying requirements for their candidate students. The statement of age range of the compulsory education in the national education system act is different with the other education regulations. Based on those situations, there are problems in this research: How is the regulation of the age for the candidate students in Indonesia primary education and How about the implementation in the elementary schools that are situated in Denpasar. This research is normative which supported by some primary data. The legal materials and primary data that collected from the field are analyzed in systematically in order to answer 2 (two) problems in this research. Based on those analyses, there is imprecision interpretation according to the age limit of the primary education candidate students. Seven years old is not the absolute requirement in enrollment the primary education candidate students. This statement is proved by SD Bali Public School which already past 2 (two) years accepting the candidate students under 7 (seven) years old and those students are still get National Student Registration Number (Nomor Induk Siswa Nasional/NISN).
\end{abstract}

Keywords: age, primary education, regulations, students

1 Penulis adalah Pengajar di bagian hukum internasional dan hukum bisnis internasional pada Fakultas Hukum Universitas Udayana, devi_salain@unud.ac.id 


\begin{abstract}
Abstrak
Pendidikan dasar merupakan jenjang pendidikan awal yang diwajibkan di Indonesia berdasarkan sistem pendidikan nasional. Sistem pendidikan nasional mensyaratkan setiap warga Negara yang berusia 7 (tujuh) tahun sampai dengan 15 (lima belas) tahun wajib mengikuti pendidikan dasar. Pernyataan inilah yang membuat kerancuan dalam menetapkan batasan usia calon peserta didik pendidikan dasar di Indonesia. Sebagai contoh, di Daerah Kota Denpasar antara Sekolah Dasar (SD) Negeri dan Swasta menetapkan persyaratan yang berbeda mengenai batasan usia penerimaan calon peserta didiknya. SD-SD Negeri mensyaratkan calon peserta didiknya minimum berusia 7 (tahun) sedangkan SD-SD Swasta lebih fleksibel menetapkan batasan usia calon peserta didiknya. Pernyataan rentang usia wajib belajar pendidikan dasar pada Undang-Undang Sistem Pendidikan Nasional berbeda dengan peraturan perundangan di bidang pendidikan lainnya. Berdasarkan keadaan tersebut, terdapat permasalahan dalam penelitian ini, yaitu: Bagaimanakah ketentuan hukum mengenai usia calon peserta didik pendidikan dasar di Indonesia dan Bagaimanakah implementasinya pada Sekolah Dasar di Daerah Kota Denpasar. Penelitian ini berjenis normatif dengan didukung beberapa data primer. Bahan-bahan hukum dan data primer yang di dapat di lapangan akan dianalisis secara sistematis sehingga dapat menjawab 2 (dua) permasalahan dalam penelitian ini. Berdasarkan analisis tersebut, terdapat ketidaktepatan interpretasi mengenai batasan usia peserta didik pendidikan dasar. Usia 7 (tujuh) tahun bukanlah syarat mutkla untuk penerimaan peserta didik pendidikan dasar. Hal ini terbukti pada SD Bali Public School yang sudah 2 (dua) tahun belakangan ini menerima calon peserta didik kurang dari 7 (tujuh) tahun dan mereka menerima Nomor Induk Siswa Nasional (NISN).
\end{abstract}

\title{
Kata Kunci: ketentuan hukum, peserta didik, pendidikan dasar, usia
}

\section{PENDAHULUAN}

Sistem pendidikan di Indonesia berdasarkan Pasal 14 Undang-Undang No. 20 Tahun 2003 tentang Sistem Pendidikan Nasional $^{2}$ mengenal 3 (tiga) jenjang pendidikan, yaitu pendidikan dasar, menengah dan tinggi. Pasal 17 Ayat (2) UU Sistem Pendidikan Nasional menyebutkan bahwa: "Pendidikan dasar berbentuk Sekolah Dasar (SD) dan Madrasah Ibtidaiyah (MI) atau bentuk lain yang sederajat serta Sekolah Menengah Pertama (SMP) dan Madrasah Tsanawiyah (MTs), atau bentuk lain

2 Selanjutnya disebut dengan UU Sistem Pendidikan Nasional yang sederajat." Pendidikan menengah dengan mengacu kepada Pasal 18 Ayat (3) UU Sistem Pendidikan Nasional adalah jenjang pendidikan lanjutan dari pendidikan dasar yang berbentuk Sekolah Menengah Atas (SMA), Madrasah Aliyah (MA), Sekolah Menengah Kejuruan (SMK), dan Madrasah Aliyah Kejuruan (MAK), atau bentuk lain yang sederajat. Jenjang pendidikan tinggi ini beragam bentuknya, mulai dari diploma, sarjana (S1), master/magister (2) dan yang terakhir adalah program doktor (S3).

Fenomena yang terjadi di masyarakat adalah persyaratan usia 
calon peserta didik pendidikan dasar. Seperti di Daerah Kota Denpasar, masing-masing SD menetapkan syaratsyarat yang berbeda mengenai batasan usia calon peserta didik. Bagi SD Negeri menetapkan batasan minimum usia calon peserta didik adalah 7 (tujuh) tahun. Kurang sebulan saja dari usia 7 (tujuh) tahun, calon peserta didik tidak dapat diterima. Persyaratan berbeda ditetapkan oleh SD Swasta (National Plus), calon peserta didik pendidikan dasar adalah berusia 6 (enam) tahun, kurang dari 6 (enam) tahun dapat diterima sepanjang kuota sekolah memenuhi, adanya rekomendasi tertulis dari psikolog profesional atau dewan guru.

Perbedaan persyaratan usia calon peserta didik pendidikan dasar menimbulkan ketidakjelasan/ kebingungan bagi SD-SD terutama para orang tua calon peserta didik. Para orang tua yang sudah menyekolahkan anaknya pada tingkat Taman KanakKanak (TK) sebelum usia 4 (empat) tahun menjadi bingung/khawatir akan kelanjutan jenjang pendidikan anaknya, apakah bisa melanjutkan ke jenjang pendidikan dasar setelah 2 (dua) tahun mengenyam TK. Di satu sisi, berkembang tren menyekolahkan anak sedini mungkin. Dulu dikenal istilah Pendidikan Anak Usia Dini (PAUD) atau Playgroup yang dimulai dari umur 2 (dua) tahun, sekarang ada istilah Todler yang diikuti oleh anakanak balita mulai usia 6 (enam) bulan. Di sisi lain ada penetapan usia calon peserta didik pendidikan dasar harus berusia 7 (tujuh) tahun. Apakah anakanak yang belum berusia 7 (tujuh) tahun harus mengenyam pendidikan TK selama 3 (tiga) tahun? Bagaimana jika anak-anak tersebut sudah mampu untuk membaca, menulis dan berhitung (calistung)? Atau sebaliknya sudah berusia 7 (tujuh) tahun tetapi belum mampu calistung.

Kemampuan anak-anak untuk calistung pada awal pendidikan dasar juga menjadi masalah. Kemampuan calistung tersebut menjadi tolak ukur/ patokan seorang calon peserta didik dapat diterima di jenjang pendidikan dasar. Hal ini jelas bertentangan dengan sistem penyelenggaraan pendidikan di Indonesia. Pasal 69 Ayat (5) Peraturan Pemerintah Republik Indonesia Nomor 17 Tahun 2010 tentang Pengelolaan dan Penyelenggaraan Pendidikan menyatakan bahwa: "Penerimaan peserta didik kelas 1 (satu) SD/MI atau bentuk lain yang sederajat tidak didasarkan ${ }^{3}$ pada hasil tes kemampuan membaca, menulis, dan berhitung, atau bentuk tes lain." Pada prakteknya semua sekolah menetapkan kemampuan calistung menjadi syarat utama setelah batasan usia untuk diterimanya seorang calon peserta didik. Keadaan ini disebabkan oleh tidak adanya sinkronisasi antara kurikulum TK dan SD. Di jenjang

3 Garis bawah diberikan oleh penulis untuk menegaskan bahwa penerimaan peserta didik pada pendidikan dasar tidak dapat menggunakan kemampuan calistung (membaca, menulis dan berhitung) sebagai tolak ukur 
TK anak- anak tidak diberikan untuk belajar calistung, mereka harus lebih banyak diberikan permainan yang sifatnya mendidik sedangkan pada jenjang SD, mereka sudah harus mampu calistung sejak pertama kali masuk SD. ${ }^{4}$

Ada beberapa ketentuan hukum yang terkait dengan penyelenggaraan pendidikan di Indonesia, yakni: Undang-Undang Nomor 20 Tahun 2003 tentang Sistem Pendidikan Nasional, Peraturan Pemerintah Republik Indonesia Nomor 17 Tahun 2010 tentang Pengelolaan dan Penyelenggaraan Pendidikan serta Peraturan Bersama antara Menteri Pendidikan dan Kebudayan Republik Indonesia dan Mentri Agama Republik Indonesia Nomor NOMOR 2/VII/ PB/2014, NOMOR 7 TAHUN 2014 tentang Penerimaan Peserta Didik

$4 \quad$ Meskipun pada kenyataannya banyak sekolahsekolah PAUD yang sudah memberikan materi calistung kepada murid didiknya karena nantinya pada saat masuk SD mereka sudah harus bisa membaca, menulis dan menghitung
Baru pada Taman Kanak-Kanak/ Raudhatul Athfal/Bustanul Athfal dan Sekolah/Madrasah. Ketiga ketentuan hukum tersebut yang akan digunakan sebagai sumber hukum utama dalam menganalisis permasalahan dalam penelitian ini.

\section{Perumusan masalah}

Adapun 2 (dua) permasalahan dalam penelitian ini, yaitu:

1. Bagaimanakah ketentuan hukum mengenai usia calon peserta didik pendidikan dasar di Indonesia?

2. Bagaimanakah implementasinya pada Sekolah Dasar di Daerah Kota Denpasar?

Dari penelusuran yang dilakukan oleh penulis, terdapat 1 (satu) artikel jurnal yang memiliki kemiripan namun esensinya berbeda. Berikut adalah tabel pembandingnya:

Tujuan Penelitian ini adalah:

1. Untuk mengetahui ketentuan hukum mengenai usia calon peserta didik pendidikan dasar di

\begin{tabular}{|c|l|l|}
\hline $\begin{array}{c}\text { Indikator } \\
\text { Pembanding }\end{array}$ & \multicolumn{1}{|c|}{ Made Suksma Prijandhini Devi Salain } & \multicolumn{1}{c|}{ Mar'atun Aslamiya Rizally } \\
\hline \multirow{3}{*}{ Judul } & $\begin{array}{l}\text { Ketentuan Hukum tentang Usia Calon Peserta } \\
\text { Didik Pendidikan Dasar Berdasarkan Sistem } \\
\text { Pendidikan Nasional di Indonesia } \\
\text { (Studi Kasus di Daerah Kota Denpasar) }\end{array}$ & $\begin{array}{l}\text { Korelasi Antara Usia Kronologis Awal } \\
\text { Masuk Sekolah Terhadap Prestasi } \\
\text { Belajar }\end{array}$ \\
\hline \multirow{5}{*}{ Permasalahan } & $\begin{array}{l}\text { Bagaimanakah ketentuan hukum } \\
\text { mengenai usia calon peserta didik pendidikan } \\
\text { dasar di Indonesia? } \\
2 . \quad \text { Bagaimanakah implementasinya } \\
\text { pada Sekolah Dasar di Daerah Kota } \\
\text { Denpasar? }\end{array}$ & $\begin{array}{l}\text { Ada indikasi korelasi antara usia anak SD } \\
\text { di bawah 7 (tujuh) tahun yang diterima } \\
\text { sebagai siswa kelas 1 SD dengan tingkat } \\
\text { pencapaian pembelajarannya }\end{array}$ \\
\hline
\end{tabular}

5 Artikel ini dimuat dalam E-JUPEKhu (Jurnal Ilmiah Pendidikan Khusus), Volume 3 Nomor 3, September 2014, http://ejournal.unp.ac.id/ index.php/jupekhu, hlm. 140 - 148 


\begin{tabular}{|c|c|c|}
\hline Kesimpulan & $\begin{array}{l}\text { 1. Terdapat beberapa ketentuan } \\
\text { hukum mengenai batasan usia calon peserta } \\
\text { didik pendidikan dasar di Indonesia, Di } \\
\text { dalam UU Sistem Pendidikan Nasional } \\
\text { terdapat } 2 \text { (dua) Pasal yang berbeda substansi } \\
\text { mengenai batasan usia calon peserta didik } \\
\text { pendidikan dasar, yaitu Pasal } 6 \text { Paragraf } 1 \\
\text { yang menyatakan usia } 7 \text { (tujuh) tahun wajib } \\
\text { belajar dan Pasal } 34 \text { Ayat (1) menyatakan } \\
\text { bahwa setiap warga Negara berusia } 6 \text { (enam) } \\
\text { tahun dapat mengikuti program wajib belajar. } \\
\text { 2. Implementasi ketentuan hukum di } \\
\text { beberapa SD (Negeri dan Swasta) di Daerah } \\
\text { Kota Denpasar adalah beragam. Kebanyakan } \\
\text { SD Negeri menetapkan syarat minimal } \\
\text { berusia } 7 \text { (tujuh) tahun bagi para calon peserta } \\
\text { didiknya sedangkan SD Swasta lebih fleksibel } \\
\text { dalam menerima peserta didiknya. SD Swasta } \\
\text { ada yang mau menerima calon peserta didik } \\
\text { berusia } 6 \text { (enam) tahun ataupun kurang dari } 6 \\
\text { (enam) tahun. SD Bali Public School menerima } \\
\text { peserta didik pendidikan dasar mulai dari usia } \\
6 \text { (enam) tahun bahkan ada } 1 \text { (satu) kelas } \\
\text { yang pesertanya berusia kurang dari } 6 \text { (enam) } \\
\text { tahun. Peserta didik yang berusia kurang dari } \\
6 \text { (enam) tahun memperoleh NISN (Nomor } \\
\text { Induk Siswa Nasional). }\end{array}$ & $\begin{array}{l}\text { Berdasarkan hasil penelitian yang telah } \\
\text { dijelaskan, yang dilaksanakan di SDN } \\
09 \text { Koto Luar Padang yang bertujuan } \\
\text { untuk mengetahui apakah terdapat } \\
\text { korelasi antara usia kronologis awal } \\
\text { masuk sekolah terhadap prestasi belajar. } \\
\text { Hasil penelitian yang telah dilaksanakan } \\
\text { menggunakan teknik korelasi Product } \\
\text { Moment yang menghasilkan rhit < } \\
\text { rtab maka Ha ditolak dan Ho diterima, } \\
\text { dengan demikian perhitungan rhit }= \\
\text { 0,081 dan } \mathrm{r} \text { tab pada taraf signifikan } \\
\text { 5\% adalah 0,291 terbukti bahwa tidak } \\
\text { terdapat korelasi antara usia awal anak } \\
\text { masuk sekolah terhadap prestasi belajar } \\
\text { siswa di SDN 09 Koto Luar, Padang. } \\
\text { Kesimpulan ini berlaku bagi ruang } \\
\text { lingkup penelitian bagi anak-anak } \\
\text { yang bersekolah di Sekolah Dasar yang } \\
\text { berusia 5,5-7 tahun }\end{array}$ \\
\hline
\end{tabular}

Indonesia mengingat pendidikan merupakan salah satu Hak Asasi Manusia (HAM);

2. Untuk mengetahui implementasi ketentuan hukum terkait pada Sekolah Dasar di Daerah Kota Denpasar.

\section{METODE PENELITIAN \\ 1. Jenis Penelitian}

Penelitian ini berjenis penelitian hukum normatif (doktrinal) dengan didukung beberapa data primer yang didapat dari lapangan. "Doctrinal Research is research which provides a systematic exposition of the rules governing a particular legal category, analyses the relationship between rules, explains areas of difficulty and, perhaps, predicts future developments". ${ }^{6}$ (Terjemahan bebas: Penelitian doktrinal adalah penelitian yang menyajikan eksposisi/pernyataan sistematis dari suatu peraturan yang mengatur kategori hukum tertentu, menganalisis hubungan antara peraturan tersebut, menjelaskan kesulitannya dan kemungkinan memprediksi perkembangan di masa yang akan datang). Penelitian ini dilakukan dengan cara meneliti bahan hukum primer, sekunder dan tersier, sehingga disebut juga penelitian non human resources yakni penelitian menggunakan bahan-bahan berupa

6 Terry Hutchinson,2002, Researching and Writing in Law, Thomson Legal \& Regulatory Limited, Australia, hlm. 9 
dokumen. ${ }^{7}$ Selain itu, penelitian ini juga menggunakan data-data yang di dapat di lapangan guna mendukung penelitian normatifnya. Suatu penelitian hukum akan bersifat utuh jika dilakukan penelitian terhadap peraturan hukumnya dan implementasinya di lapangan.

\section{Sumber Bahan Hukum dan Data Primer}

Penelitian ini menggunakan 3 (tiga) jenis sumber bahan hukum, yakni: bahan hukum primer, sekunder dan tersier. ${ }^{8}$ Penelitian ini menggunakan bahan hukum primer berupa peraturan perundang-undangan terkait pendidikan; sedangkan bahan hukum sekunder berupa buku-buku, artikel jurnal (cetak maupun online) dan karya tulis ilmiah ahli hukum; Bahan hukum tersier berupa kamus ataupun ensiklopedia. Data primer yang didapat melalui observasi dan wawancara di lapangan juga digunakan dalam penelitian ini.

\section{Tehnik Pengumpulan dan Analisis Bahan Hukum}

Bahan-bahan hukum baik yang primer maupun sekunder diinventarisir terlebih dahulu kemudian dilakukan studi kepustakaan sedangkan data primer yang didapat di lapangan diperoleh dengan cara melakukan

7 Nasution, 1998, Metode Penelitian Naturalistik Kualitatif, Tarsito, Bandung, hlm. 85

8 Bahder Johan Nasution, 2011, Negara Hukum dan Hak Asasi Manusia, Mandar Maju, Bandung, hlm. 97 observasi dan wawancara. Setelah bahan-bahan hukum dan data primer terkumpul maka dianalisis secara kualitatif melalui langkah-langkah deskripsi, interpretasi, sistematisasi, argumentasi dan evaluasi.

III. HASIL DAN PEMBAHASAN 3.1 Ketentuan Hukum Usia Calon Peserta Didik Pendidikan Dasar di Indonesia

Pendidikan merupakan salah satu Hak Asasi Manusia (HAM). HAM adalah sekelompok hak yang dimiliki oleh manusia, hanya manusialah sebagai subyek hukum alami (orang perseorangan/individu) yang menyandang HAM bukan subyek hukum buatan lainnya, seperti badan hukum dan Negara. Kelompokkelompok individu pada waktu tertentu dapat memiliki HAM untuk melindungi kelompoknya namun berbeda penggunaannya dengan HAM yang dimiliki oleh setiap orang. ${ }^{9}$ Berdasarkan Pasal 1 Angka 1 UndangUndang Nomor 39 Tahun 1999 tentang Hak Asasi Manusia, "Hak Asasi Manusia adalah seperangkat hak yang melekat pada hakikat dan keberadaan manusia sebagai makhluk Tuhan Yang Maha Esa dan merupakan anugerah-Nya yang wajib dihormati, dijunjung tinggi dan dilindungi oleh

\footnotetext{
9 Jeremy Waldron, Taking Group Rights Carefully dalam Grant Hus Cropt \& Paul Risworth (eds.), Litigating Rights, h. 203220 dalam Pranoto Iskandar, 2012, Hukum Hak Asasi Manusia Internasional: Sebuah Pengantar Kontekstual, IMR Press, Cianjur, hlm. 67
} 
negara, hukum dan Pemerintah, dan setiap orang demi kehormatan serta perlindungan harkat dan martabat manusia".

\section{Karakteristik HAM}

Berdasarkan Paragraf 1 Pembukaan Deklarasi Hak Asasi Manusia 1948 bersifat absolut (inalienable) dan tidak dapat direnggut dari seseorang. HAM akan terus melekat pada seseorang sepanjang hidupnya sebagai manusia tanpa mempermasalahkan apakah individu bersangkutan seorang penjahat, pencuri, pemerkosa ataupun pahlawan. Selain itu, seorang individu tidak bisa melepaskan HAM-nya secara sukarela karena tidak menginginkannya. HAM melekat pada setiap manusia sejak dilahirkan ke dunia, baik dikehendaki ataupun tidak.

Karakteristik HAM tersebut menurut Nickel bukan berarti tidak dapat dibatasi oleh keadaan lain. Sebagai contoh seseorang melakukan pembunuhan dan dipenjara. Selama dipenjara pembunuh tersebut tidak bisa bergerak dengan bebas seperti individu lain yang tidak melakukan kejahatan. HAM pembunuh tersebut untuk sementara waktu dibatasi selama dipenjara. Dengan kata lain, HAM adalah hak yang tidak dapat ditanggalkan (hard to lose). ${ }^{10}$

Seperti yang telah disebutkan diatas bahwa HAM adalah hak yang tidak dapat ditanggalkan, ini berarti HAM adalah hak yang sangat fundamental. Hak adalah hal yang penting (cogent) bagi seorang individu untukmengklaim sesuatu. Kepemilikan HAM oleh seorang individu tentunya berbeda dengan hak seseorang terhadap suatu benda (kepemilikan benda). Perbedaannya terletak pada nilai keutamaan yang terdapat di dalam HAM. HAM merupakan atribut manusia yang bersifat instrinsik. Setiap individu memiliki HAM karena atributnya sebagai manusia bukan karena alasan lainnya. ${ }^{11}$

Karakteristik HAM yang demikian dikuatkan dengan Teori Keadilan dari John Rawls yang mengkritik konsep keadilan menurut aliran utilitarianisme yang mengutamakan kesejahteraan namun mengabaikan unsur keadilan (hak) yang sesungguhnya merupakan hal fundamental bagi masyarakat demokratis. Menurut John Rawls, konsep keadilan tidak dapat diganggu gugat meskipun bertujuan untuk mencapai kesejahteraan masyarakat secara keseluruhan. Berdasarkan hal tersebut John Rawls mengemukakan kontrak sosial yang mengandung 2 (dua) prinsip keadilan, yaitu:

"(1) each person is to have an equal right to the most extensive basic liberty compatible with a similar liberty for others; (2) social and economic inequalities are to be arranged so that they are both [a] reasonably expected

10 Pranoto Iskandar, loc.cit.

11 Stephen James, 2007, Universal Human Rights: Origins and Developments, LFB Scholarly Publishing, New York, hlm. 117 
to be to everyone's advantage, and [b] attached to positions and offices open to all." 12

Keadilan menurut teori ini bahwa semua orang memiliki hak yang sama atas kebebasan dasar, ketimpangan sosial dan ekonomi harus diatur sedemikian rupa sehingga dapat memberikan manfaat bagi semua orang serta semua posisi dan jabatan terbuka untuk semua orang. Atau dengan kata lain, dapat dikatakan bahwa ketidakadilan adalah jika ketimpangan/ketidaksamaan (inequality) pendistribusian akan hak, kesempatan dalam ekonomi, pekerjaan, pendidikan dan lainnya tidak memberikan manfaat bagi semua orang. ${ }^{13}$

\section{Generasi dalam HAM}

Berdasarkan literatur buku-buku hukum terdapat 3 (tiga) generasi HAM, yaitu: Generasi Pertama, Kedua dan Ketiga. Berikut adalah penjabarannya:

\section{HAM Generasi Pertama}

Pada generasi ini, HAM yang berkembang adalah hak-hak mengenai kebebasan individu yang berkaitan erat dengan hak sipil dan politik. Pada saat itu manusia sudah mulai sadar bahwa mereka adalah individu yang memiliki kebebasan, tidak ingin terikat

12 John Rawls, 1971, A Theory of Justice, The Belknap Press of Harvard University Press Cambridge, Massachusetts, hlm. 60

13 John Rawls, 2011, A Theory of Justice; Teori Keadilan Dasar-Dasar Filsafat Politik untuk Mewujudkan Kesejahteraan Sosial dalam Negara, Cet. II, Pustaka Pelajar, Yogyakarta, hlm. 74 . oleh kekuasaan

absolut sebuah Negara, mereka ingin melindungi kehidupan pribadinya sebagai manusia. HAM generasi pertama diusulkan oleh Negara-Negara barat yang sudah maju secara ekonomi, sosial maupun budaya. Oleh karena itu mereka memandang diperlukannya hak- hak kebebasan di bidang sipil dan politik yang dituangkan dalam International Covenant on Civil and Political Rights (ICCPR) 1966. HAM Generasi Pertama meminimalisir peran dari Negara untuk penyelenggaraannya, karena semakin banyak Negara intervensi maka akan terjadi pelanggaran terhadap HAM tersebut. Adapun beberapa hak yang dapat digolongkan dalam HAM Generasi Pertama, yakni: hak untuk menentukan nasib sendiri, hak untuk hidup, hak untuk tidak dihukum mati, hak untuk tidak disiksa, hak untuk tiak ditahan secara sewenang-wenang, hak untuk peradilan yang adil, independen dan tidak berpihak, hak untuk berekspresi dan menyampaikan pendapat, hak untuk berkumpul dan berserikat, hak untuk mendapatkan persamaan perlakuan di depan hukum serta hak untuk dipilih dan memilih. ${ }^{14}$

\section{HAM Generasi Kedua}

HAM pada generasi ini diusulkan oleh Negara-Negara Timur yang secara ekonomi, sosial dan budaya belum terpenuhi. Oleh sebab itu mereka lebih

14 Jimly Ashidiqqie, 2007, Pokok-Pokok Hukum Tata Negara Indonesia Pasca Reformasi, Penerbit: PT BIP (Kelompok Gramedia), Jakarta, hlm. 623. 
mengutamakan hak-hak di bidang ekonomi, sosial dan budaya sebagai HAM. Hak-hak tersebut dituangkan dalam International Covenant on Economic, Social and Cultural Rights (ICESCR) 1966. HAM Generasi Kedua ini sangat berbeda dengan generasi yang pertama. Pada HAM Generasi Pertama, Negara tidak berperan aktif dalam penyelenggaraan hak-hak sipil dan politik sedangkan pada generasi kedua, Negara dituntut aktif untuk berperan serta dalam penyelenggaraan hak-hak di bidang ekonomi, sosial dan budaya. Oleh sebab itu HAM digolongkan sebagai HAM Generasi Kedua adalah: hak untuk bekerja, hak untuk mendapatkan upah yang sama, hak untuk tidak dipaksa bekerja, hak untuk cuti, ha katas makanan, hak atas perumahan, ha katas kesehatan, hak atas pendidikan, hak untuk berpartisispasi dalam kegiatan kebudayaan, hak untuk menikmati kemajuan ilmu pengetahuan, hak untuk memperoleh perlindungan atas hasil karya cipta (hak cipta). ${ }^{15}$

\section{HAM Generasi Ketiga}

HAMGenerasiKetigainipertama kali dimuat dalam African Charter on Human and Peoples Rights 1981. African Charter ini merupakan terobosan baru di dunia HAM. HAM tidak hanya dimiliki oleh setiap individu tetapi juga ada hak-hak yang dimiliki oleh sebuah kom unitas, kelompok individu atau group. HAM

15 Ibid., hlm. 624
Generasi ketiga ini berkaitan dengan Pembangunan, diantaranya adalah hak untuk mendapatkan pembangunan (perumahan) yang layak, hakuntuk mendapatkan lingkungan hidup yang bersih dan hak untuk mendpaatkan air bersih. ${ }^{16}$ Kemunculan HAM Generasi Ketiga ini terlihat dari kondisi Negaranegara Afrika yang serba kekurangan di bidang pembangunan.

\section{Hak Atas Pendidikan Sebagai Salah Satu HAM}

Dengan melihat uraian diatas mengenai generasi HAM maka hak atas pendidikan merupakan hak dari HAM Generasi Kedua (hak ekonomi, sosial dan budaya). Sebelum terbentuknya ICESCR, ha katas pendidikan sudah secara jelas dimuat dalam Pasal 26 Ayat (1) Deklarasi Hak Asasi Manusia 1948:

"Everyone has the right to education. Education shall be free, at least in the elementary and fundamental stages. Elementary education shall be compulsory. Technical and professional education shall be made generally available and higher education shall be equally accessible to all on the basis of merit."

Setiap orang mempunyai hak untuk menikmati pendidikan tanpa terkecuali, usia muda-usia tua, orang desa-orang kota, orang miskin-orang kaya, pria-wanita. Pada Pasal 26 Ayat (1) tersebut juga ditegaskan bahwa pendidikan dasar adalah absolut/wajib dinikmati oleh setiap individu.

16 Ibid., hlm. 625 
Jenjang pendidikan dasar adalah dasarsetiapindividuyanginginmemulai pendidikan. Oleh karena itu setiap individu wajib harus menikmatinya. Disinilah diperlukannya peran Negara untuk menyelenggarakan sistem pendidikan yang baik sehingga semua orang/setiap individu dapat mengenyam pendidikan. Pasal 2 Ayat (1) ICESCR menyatakan: "Each State Party to the present Covenant undertakes to take steps, individually and through international assistance and co-operation, especially economic and technical, to the maximum of its available resources, with a view to achieving progressively the full realization of the rights recognized in the present Covenant by all appropriate means, including particularly the adoption of legislative measures."

Pasal tersebut diatas dengan jelas menyatakan bahwa kewajiban setiap Negara anggota ICESCR untuk mengambil langkah-langkah baik secara nasional maupun internasional untuk merealisasikan hak-hak yang diakui dalam ICESCR, termasuk hak atas pendidikan. Inilah yang sering disebutdengankewajibanpositifsebuah Negara. Meskipun keputusan (hak) untuk memilih sekolah tetap berada pada setiap orang tua, Negara wajib menyediakan sarana dan prasarana untuk penyelenggaraan pendidikan. ${ }^{17}$ Apabila sebuah Negara tidak mau menyediakan atau memfasilitasi

17 Pasal 26 Ayat (3) Deklarasi Hak Asasi Manusia 1948 : "Parents have a prior right to choose the kind of education that shall be given to their children" penyelenggaraan pendidikan maka Negara tersebut dapat dituntut di muka pengadilan.

Ketentuan dalam instrumen internasional tersebut juga sudah ditransformasi ke dalam hukum nasional Indonesia melalui UU Sistem Pendidikan Nasional. Hal ini dapat terlihat pada Pasal 5 Ayat (1) UU Sistem Pendidikan Nasional : "Setiap warga negara mempunyai hak yang sama untuk memperoleh pendidikan yang bermutu". Pasal 7 Ayat (1) UU yang sama menyebutkan: "Orang tua berhak berperan serta dalam memilih satuan pendidikan dan memperoleh informasi tentang perkembangan pendidikan anaknya." Peran Negara dan Pemerintah termuat dalam Pasal 10 UU Sistem Pendidikan Nasional: "Pemerintah dan Pemerintah Daerah berhak mengarahkan, membimbing, membantu, dan mengawasi penyelenggaraan pendidikan sesuai dengan peraturan perundang-undangan yang berlaku" dan Pasal 11 yaitu: "Pemerintah dan Pemerintah Daerah wajib memberikan layanan dan kemudahan, serta menjamin terselenggaranya pendidikan yang bermutu bagi setiap warga negara tanpa diskriminasi”.

Melihat dari UU Sistem Pendidikan Nasional, Indonesia sebagai Negara yang berdaulat sudah memenuhi kewajibannya untuk menyelenggarakan pendidikan bagi setiap warga negaranya tanpa terkecuali. Indonesia sadar akan 
pentingnya pendidikan bagi warga negaranya. Hal ini terbukti dari Pasal 3 UU Sistem Pendidikan Nasional yang menyebutkan bahwa "Pendidikan Nasional berfungsi mengembangkan kemampuan dan membentuk watak serta peradaban bangsa yang bermartabat dalam rangka mencerdaskan kehidupan bangsa, bertujuan untuk berkembangnya potensi peserta didik agar menjadi manusia yang beriman dan bertakwa kepada Tuhan Yang Maha Esa, berakhlak mulia, sehat, berilmu, cakap, kreatif, mandiri danmenjadi warga Negara yang demokratis serta bertanggungjawab".

Ketentuan hukum sistem pendidikan nasional menjadi tidak jelas jika dikaitkan dengan batasan usia peserta didik pendidikan dasar. Ketidakjelasan ini dapat dilihat pada Pasal 6 Paragraf 1 UU Sistem Pendidikan Nasional: "Setiap warga negara yang berusia tujuh sampai denganlimabelastahunwajibmengikuti pendidikan dasar." Kemudian Pasal 34 Ayat (1) UU Sistem Pendidikan Nasional menyatakan: "Setiap warga negara yang berusia 6 (enam) tahun dapat $^{18}$ mengikuti program wajib belajar." Kedua pasal ini memberikan batasan usia yang berbeda mengenai calon peserta didik pendidikan dasar di Indonesia meskipun berada di dalam UU yang sama.

18 Garis bawah diberikan oleh Peneliti untuk menunjukkan bahwa anak usia 6 (enam) tahun dapat diterima menjadi peserta didik pendidikan dasar
Pasal 69 Peraturan Pemerintah Republik Indonesia Nomor 17 Tahun 2010 tentang Pengelolaan dan Penyelenggaraan Pendidikan menyebutkan bahwa:

"(1) Peserta didik pada SD/MI atau bentuk lain yang sederajat paling rendah berusia 6 (enam) tahun.;

(2) Pengecualian terhadap ketentuan pada ayat (1) dapat dilakukan atas dasar rekomendasi tertulis dari psikolog profesional;

(3) Dalam hal tidak ada psikolog profesional, rekomendasi dapat dilakukan oleh dewan guru satuan pendidikan yang bersangkutan, sampai dengan batas daya tampungnya;

(4) SD/MI atau bentuk lain yang sederajat wajib menerima warga negara berusia 7 (tujuh) tahun sampai dengan 12 (dua belas) tahun sebagai peserta didik sampai dengan batas daya tampungnya."

Peraturan Pemerintah ini secara jelas menetapkan bahwa batas minimum usia calon peserta didik adalah 6 (enam) tahun namun diberikan pengecualian bagi anak-anak yang usianya kurang dari 6 (enam) tahun sepanjang ada rekomendasi dari psikolog profesional atau dewan guru dan sesuai dengan daya tampung sekolahnya. Kemudian Pasal 69 Ayat (4) menyatakan bahwa SD wajib menerima warga Negara berusia 7 (tujuh) tahun sebagai peserta didik. Pernyataan Pasal ini mengandung 
pengertian bahwa anak-anak yang sudah berusia 7 (tujuh) tahun wajib mengikuti jenjang pendidikan dasar. Tujuan dari Pasal ini untuk anak-anak atau calon peserta didik yang berada di pelosok-pelosok (desa), karena banyak anak-anak di daerah tersebut yang memulai pendidikan dasar melebihi usia 7 (tujuh) tahun. Para orang tua di daerah pelosok (desa) sering tidak menyekolahkan anaknya mulai dari jenjang Taman Kanak-Kanak (TK) dengan alasan ekonomi atau tidak tanggap informasi. Jadi, sesungguhnya syarat minimum 7 (tujuh) tahun bagi calon peserta didik pendidikan dasar bukanlah menjadi keharusan/syarat mutlak ketika seorang anak menjadi calon peserta didik.

Ketidaktepatan interpretasi inilah yang digunakan oleh beberapa SD Negeri di Daerah Kota Denpasar untuk menetapkan persyaratan penerimaan calon peserta didik pendidikan dasar. SD-SD Negeri mengambil langkah seperti itu dengan alasan untuk memudahkan mereka dalam menyeleksi calon peserta didik. Alasan lainnya, peserta didik yang usianya kurang dari 6 (enam) di SD Swasta dan kurang dari 7 (tujuh) tahun di SD Negeri tidak dapat mengikuti ujian akhir kelas 6 (enam) SD karena tidak memiliki Nomor Induk Siswa Nasional (NISN). Lalu bagaimana dengan anak-anak percepatan? Mereka juga belum cukup umur untuk jenjang pendidikan yang ditempuhnya. Misalkan saja, seperti Aldo Melloya
Geraldino sudah tercatat sebagai mahasiswa Fakultas Kedokteran Universitas Gajah Mada pada usia 14 tahun. Aldo sudah mengenyam pendidikan dasar pada usia 5,5 (lima setengah) tahun dan terbukti ia bisa mengikuti jenjang pendidikan selanjutnya dengan baik dan sekarang diterima menjadi mahasiswa termuda di Fakultas Kedokteran Universitas Gadjah Mada. ${ }^{19}$

Interpretasi yang tidak tepat mengenai usia calon peserta didik menjadi lebih kuat dengan adanya Peraturan Bersama antara Menteri Pendidikan dan Kebudayan Republik Indonesia dan Mentri Agama Republik Indonesia Nomor NOMOR 2/VII/ PB/2014, NOMOR 7 TAHUN 2014 tentang Penerimaan Peserta Didik Baru pada Taman Kanak-Kanak/Raudhatul AthFal/Bustanul

Athfal dan Sekolah/Madrasah. Pada peraturan Menteri bersama ini, syarat calon peserta didik pendidikan dasar telah berusia 7 (tujuh) tahun pada ayat 1 (pertama): ${ }^{20}$

"(1) Persyaratan calon peserta didik baru kelas 1 (satu) pada SD/ SDLB/MI/sederajat pada tanggal 1 Juli tahun berjalan:

19 Aldo Meyolla Geraldino, Usia 14 tahun Kuliah di UGM, http://ugm.ac.id/id/berita/10281aldo.meyolla.geraldino.usia.14.tahun.kuliah. di.ugm, diunduh pada tanggal 15 Maret 2016.

2020 Pasal 4 Peraturan Bersama antara Menteri Pendidikan dan Kebudayan Republik Indonesia dan Mentri Agama Republik Indonesia Nomor NOMOR 2/VII/PB/2014, NOMOR 7 TAHUN 2014 tentang Penerimaan Peserta Didik Baru pada Taman Kanak-Kanak/Raudhatul AthFal/ Bustanul Athfal dan Sekolah/Madrasah 
a. telah berusia 7 (tujuh) tahun sampai dengan 12 (dua belas) tahun wajib diterima;

b. telah berusia berusia 6 (enam) tahun dapat diterima;

c. telah berusia berusia 5 (lima) tahun sampai dengan kurang dari 6 (enam) tahun, dapat dipertimbangkan atas rekomendasi tertulis dari psikolog profesional; dan

d. berusia kurang dari 5 (lima) tahun tidak dapat diterima.

(2) Dalam hal tidak ada psikolog profesional sebagaimana dimaksud pada ayat (1) huruf c, rekomendasi dapat dilakukan oleh dewan guru SD/ SDLB/MI/sederajat yang bersangkutan sampai dengan batas tampungnya terpenuhi sesuai standar pelayanan minimal pendidikan dasar."

Syarat calon peserta didik baru (pendidikan dasar) telah berusia 7 (tujuh) tahun pada ayat (1) diatas menyebabkan banyak pihak (SD-SD Negeri dan Swasta) yang menginterpretasikan bahwa anak yang sudah berusia 7 (tujuh) tahun (tidak boleh kurang satu bulan saja) baru dapat diterima sebagai calon peserta didik pendidikan dasar.

\subsection{Implementasi ketentuan}

hukum tentang batasan usia calon peserta didik pendidikan dasar pada Sekolah Dasar di Daerah Kota Denpasar

Penetapan batas usia calon peserta didik pendidikan dasar pada Sekolah Dasar (SD) di Daerah Kota Denpasar sudah menjadi polemik sejak 2 - 3 tahun yang lalu. Para orang tua murid yang memiliki anak kurang dari 7 (tujuh) tahun namun sudah tamat TK dan akan mencari SD menjadi resah dengan ketentuan beberapa SD yang menyaratkan peserta didiknya minimal 7 (tujuh) tahun. Mereka mulai mensurvei SDSD yang dapat menerima peserta didik pendidikan dasar kurang dari usia 7 (tujuh) tahun. Keadaan ini ditimbulkan dari ketidakjelasan ketentuan hukum mengenai batasan usia peserta didik pendidikan.

Adanya 2 (dua) pasal yang berbeda substansinya di dalam UU Sistem Pendidikan Nasional menjadi sumber ketidakjelasan batasan usia calon peserta didik pendidikan dasar. Pasal 6 Paragraf 1 UU Sistem Pendidikan Nasional: "Setiap warga negara yang berusia tujuh sampai dengan lima belas tahun wajib mengikuti pendidikan dasar." Kemudian Pasal 34 Ayat (1) UU Sistem Pendidikan Nasional menyatakan: "Setiap warga negara yang berusia 6 (enam) tahun dapat mengikuti program wajib belajar." SD - SD di Daerah Kota Denpasar cenderung mengikuti bunyi Pasal 6 Paragraf 1 UU Sistem Pendidikan Nasional dan salah menginterpretasikannya sehingga mereka menerapkan batasan usia calon peserta didik pendidikan dasar minimum 7 (tujuh) tahun. Selain 
itu, dari hasil observasi di beberapa SD di Daerah Kota Denpasar (SD Bali Public School, SD 5 Saraswati, SD Negeri 8 Dauh Puri dan SD Negeri No. 2 Kesiman), para kepala sekolahnya menyatakan kurangnya sosialisasi mengenai ketentuan hukum penyelenggaraan pendidikan. Banyak terdapat ketentuan-ketentuan hukum/ kebijakan dari Kementrian Pendidikan dan Kebudayaan yang belum sempat tersosialisasikan bahkan sudah diganti dengan kebijakan yang baru.

Suatu Undang-Undang dapat dilaksanakan apabila sudah dibuatkan Peraturan Pelaksananya berupa Peraturan Pemerintah. UU Sistem Pendidikan Nasional sudah memiliki Peraturan pelaksananya, yaitu: Peraturan Pemerintah Republik Indonesia No. 17 Tahun 2010 tentang Pengelolaan dan Penyelenggaraan Pendidikan. Pasal 69 Peraturan Pemerintah tersebut menyatakan bahwa:

“(1) Peserta didik pada SD/MI atau bentuk lain yang sederajat paling rendah berusia 6 (enam) tahun.;

(2) Pengecualian terhadap ketentuan pada ayat (1) dapat dilakukan atas dasar rekomendasi tertulis dari psikolog profesional;

(3) Dalam hal tidak ada psikolog profesional, rekomendasi dapat dilakukan oleh dewan guru satuan pendidikan yang bersangkutan, sampai dengan batas daya tampungnya;

(4) $\mathrm{SD} / \mathrm{MI}$ atau bentuk lain yang sederajat wajib menerima warga negara berusia 7 (tujuh) tahun sampai dengan 12 (dua belas) tahun sebagai peserta didik sampai dengan batas daya tampungnya."

Berdasarkan Pasal 69 Peraturan Pemerintah tentang Pengelolaan dan Penyelenggaraan Pendidikan sudah jelas menyatakan bahwa calon peserta didik pendidikan dasar minimum berusia 6 (enam) tahun, jika kurang dari 6 (enam) tahun dapat diterima dengan adanya rekomendasi tertulis dari psikolog profesional atau dewan guru. Kemudian Ayat (4) dari Pasal 69 ini menyebutkan bahwa SD wajib menerima warga Negara berusia 7 (tujuh) tahun sebagai peserta didik. Pasal ini dimaksudkan untuk menerima anak-anak yang sudah berusia 7 (tujuh) tahun sebagai peserta didik. Usia 7 (tujuh) tahun dianggap sebagai batas maksimum usia peserta didik pendidikan dasar.

Dinas Pendidikan Pemuda dan Olah Raga Provinsi Bali telah memberikan Surat Edaran Nomor 420/10712/DISDIKPORA tertanggal 3 Juni 2015 kepada Kepala Dinas Pendidikan Pemuda dan Olah Raga Kabupaten dan Kota se-Bali bahwa pedoman pelaksanaan Persyaratan Peserta Didik Baru (PPDB) berdasarkan Peraturan Bersama antara Menteri Pendidikan dan Kebudayan Republik Indonesia dan Mentri Agama Republik Indonesia Nomor NOMOR 2/VII/PB/2014, NOMOR 7 TAHUN 2014 tentang Penerimaan Peserta Didik 
Baru pada Taman Kanak-Kanak/ Raudhatul AthFal/Bustanul Athfal dan Sekolah/Madrasah. Surat edaran ini menegaskan bahwa persyaratan penerimaan calon peserta didik baru tidak mutlak berusia 7 (tujuh) tahun. Bahkan anak berusia kurang dari 6 (enam) tahun dapat diterima sebagai calon peserta didik pendidikan dasar sepanjang memenuhi persyaratan yang telah ditentukan.

Sampai dengan diturunkannya Surat Edaran Nomor 420/10712/ DISDIKPORA masih banyak SD-SD di Daerah Kota Denpasar (terutama SD-SD Negeri) yang tidak mau menerima calon peserta didik dengan usia kurang dari 7 (tujuh) tahun. Salah satu alasannya, apabila peserta didik yang berusia kurang dari 7 (tujuh) tahun diterima maka yang bersangkutan dapat mengikuti proses belajar mengajar namun tidak memperoleh NISN (Nomor Induk Siswa Nasional). NISN ini adalah salah satu syarat yang harus dimiliki peserta didik untuk mengikuti ujian akhir nasional di tingkat kelas VI SD. Apabila tidak memiliki NISN maka peserta didik tidak dapat mengikuti ujian akhir nasional di tingkat kelas VI SD.

Keadaan tersebut diatas sesungguhnya tidak dapat digunakan sebagai alasan pembenar untuk tidak menerima peserta didik pendidikan dasar yang usianya kurang dari 7 (tujuh) tahun. SD Bali Public School sebagai salah satu SD Nasional Plus di
Daerah Kota Denpasar sampai dengan sekarang ini masih menerima peserta didik dengan usia 6 (enam) tahun atau kurang dari 6 (enam) tahun dan mereka tetap mendapatkan NISN. Berdasarkan wawancara dengan Kepala Sekolah SD Bali Public School, Bapak Komang Edi Putra, S. Ag., SD Bali Public School memang menerima peserta didik dengan usia 6 (enam) tahun ataupun kurang dari 6 (enam) tahun. Hal ini tidaklah melanggar ketentuan karena memang diperbolehkan menerima peserta didik dengan usia 6 (enam) tahun atau kurang dari 6 (enam) tahun berdasarkan Peraturan Pemerintah tentang Pengelolaan dan Penyelenggaraan Pendidikan dan Peraturan Bersama antara Menteri Pendidikan dan Kebudayan Republik Indonesia dan Mentri Agama Republik Indonesia Nomor NOMOR 2/VII/ PB/2014, NOMOR 7 TAHUN 2014 tentang Penerimaan Peserta Didik Baru pada Taman Kanak-Kanak/ Raudhatul Athfal/Bustanul Athfal dan Sekolah/Madrasah. Disamping itu, daya tampung SD Bali Public School juga masih memadai. Setiap tahunnya SD Bali Public School menerima peserta didik baru sejumlah $80-100$ orang dengan perhitungan perkelas menampung $20 \quad-25$ orang peserta didik.

Pada tahun ajaran baru 2016, SD Bali Public School menerima 4 (empat) buah kelas 1, yaitu: 1A, 1B, $1 \mathrm{C}$ dan 1D. Kelas dibagi sesuai usia peserta didik. Kelas 1A terdiri dari 
peserta didik yang terlahir di bulan Januari begitu seterusnya sampai dengan Kelas 1D. Khusus untuk peserta didik di Kelas 1D terdiri dari anak-anak yang umurnya kurang dari 6 (enam) tahun tetapi mereka lolos tes calistung pada saat penerimaan di SD Bali Public School. Kelas 1D di SD Bali Public School terdiri dari 18 (delapan belas) orang peserta didik dan mereka semua telah memperoleh NISN. Berikut adalah nama-nama peserta didik di Kelas 1D SD Bali Public School:
Bapak Edi Putra selaku Kepala Sekolah di SD Bali Public School juga menyampaikan bahwa para peserta didik di Kelas 1D juga mampu bersaing secara akademis dengan peserta didik di Kelas 1A, 1B dan 1C. Peserta didik di kelas 1D sering menjuarai lomba-lomba yang diselenggarakan di lingkungan SD Bali Public School.

Data mengenai peserta didik Kelas 1D di SD Bali Publis School menunjukkan bahwa isu yang berkembang di masyarakat dan penerapan syarat minimum usia 7

Tabel Daftar Nama Siswa Kelas 1D SD Bali Public School dengan Usia kurang dari 6 (enam) Tahun

\begin{tabular}{|c|c|c|c|}
\hline NO & NIS & NISN & NAMA LENGKAP \\
\hline 1 & 672 & 0104908974 & Anak Agung Istri Fresthi Dwi Laksita \\
\hline 2 & 673 & 0109179019 & Anak Agung Intan Ayu Larasati \\
\hline 3 & 674 & 0101037683 & Anak Agung Ngurah Ardra Maheswara \\
\hline 4 & 675 & 0102262346 & I Gusti Ayu Aira Krishna Devi \\
\hline 5 & 676 & 0103401708 & I Putu Bagus Ngurah Arya Wibawa \\
\hline 6 & 677 & 0104096367 & I Wayan Pixel Junior Sentosa \\
\hline 7 & 678 & 0101739705 & Ida Bagus Kade Mahawira Samjaya \\
\hline 8 & 679 & 0101954433 & Kadek Nalini Aishwarya Widhiana \\
\hline 9 & 680 & 0104855560 & Ni Kadek Chandani Paramesti \\
\hline 10 & 681 & 0106645889 & Ni Luh Putu Masayu Kharismaputri \\
\hline 11 & 682 & 0102005324 & Ni Putu Dian Chandradevi \\
\hline 12 & 683 & 0107190243 & Ni Putu Natasha Putri Aristhadevi \\
\hline 13 & 684 & 0109334901 & Putu Gita Aishwarya Sanjiani \\
\hline 14 & 685 & 0106769268 & Putu Janarkka Syailendra Putra \\
\hline 15 & 686 & 0101722451 & Putu Kanza Maharani Putri \\
\hline 16 & 687 & 0101704470 & Putu Kayla Arinagata Hendra \\
\hline 17 & 688 & 0109773847 & Putu Serafine Lakhsmi Sugiantara \\
\hline 18 & 689 & 0109141463 & Ni Putu Sri Ratih Satyananda \\
\hline
\end{tabular}

Sumber: Data Siswa Tahun Ajaran 2015 SD Bali Public School 
(tujuh) tahun bagi calon peserta didik pendidikan dasar di beberapa SD di Daerah Kota Denpasar tidaklah benar. SD Bali Public School membuktikan bahwa peserta didik mereka ada yang berusia 6 (enam) tahun bahkan ada 18 (delapan belas) orang yang berusia kurang dari 6 (enam) tahun. Terlebih peserta didik yang kurang dari 6 (enam) tahun tersebut telah memperoleh NISN sehingga dapat mengikuti ujian akhir nasional di tingkat Kelas VI SD.

\section{KESIMPULAN}

1. Terdapat beberapa ketentuan hukum mengenai batasan usia calon peserta didik pendidikan dasar di Indonesia, yaitu: UU Sistem Pendidikan Nasional, Peraturan Pemerintah tentang Pengelolaan dan Penyelenggaraan Pendidikan dan Peraturan Bersama antara Menteri Pendidikan dan Kebudayan Republik Indonesia dan Mentri Agama Republik IndonesiaNomorNOMOR2/VII/ PB/2014, NOMOR 7 TAHUN 2014 tentang Penerimaan Peserta Didik Baru pada Taman Kanak-Kanak/Raudhatul Athfal/ Bustanul Athfal dan Sekolah/ Madrasah. Di dalam UU Sistem Pendidikan Nasional terdapat 2 (dua) Pasal yang berbeda substansi mengenai batasan usia calon peserta didik pendidikan dasar, yaitu Pasal 6 Paragraf 1 yang menyatakan usia 7 (tujuh) tahun wajib belajar dan Pasal 34 Ayat (1) menyatakan bahwa setiap warga Negara berusia 6 (enam) tahun dapat mengikuti program wajib belajar.

2. Implementasi ketentuan hukum di beberapa SD (Negeri dan Swasta) di Daerah Kota Denpasar adalah beragam. Kebanyakan SD Negeri menetapkan syarat minimal berusia 7 (tujuh) tahun bagi para calon peserta didiknya sedangkan SD Swasta lebih fleksibel dalam menerima peserta didiknya. SD Swasta ada yang mau menerima calon peserta didik berusia 6 (enam) tahun ataupun kurang dari 6 (enam) tahun. SD Swasta berani menerapkan syarat demikian karena sudah ada Surat Edaran dari Pemerintah Daerah Provinsi Bali Nomor 420/10712/ DISDIKPORA yang mengacu pada Peraturan Bersama antara Menteri Pendidikan dan Kebudayan Republik Indonesia dan Mentri Agama Republik IndonesiaNomorNOMOR2/VII/ PB/2014, NOMOR 7 TAHUN 2014 tentang Penerimaan Peserta Didik Baru pada Taman Kanak-Kanak/Raudhatul Athfal/Bustanul Athfal dan Sekolah/Madrasah. SD Bali Public School sebagai salah satu sekolah dasar nasional plus di Daerah Kota Denpasar menerima peserta didik pendidikan dasar 
mulai dari usia 6 (enam) tahun bahkan ada 1 (satu) kelas yang pesertanya berusia kurang dari 6 (enam) tahun. Peserta didik yang berusia kurang dari 6 (enam) tahun kenyataannya memperoleh NISN (Nomor Induk Siswa Nasional), dengan kata lain mereka sah menjadi peserta didik pada jenjang pendidikan dasar dan berhak mengikuti ujian akhir nasional di tingkat Kelas VI SD.

\section{DAFTAR PUSTAKA}

Bahder Johan Nasution, 2011, Negara Hukum dan Hak Asasi Manusia, Mandar Maju, Bandung

Jimly Ashidiqqie, 2007, Pokok-Pokok

Hukum Tata Negara Indonesia Pasca Reformasi, Penerbit: PT BIP (Kelompok Gramedia), Jakarta

John Rawls, 1971, A Theory of Justice,

The Belknap Press of Harvard University Press Cambridge, Massachusetts.

-----, 2011, A Theory of Justice; Teori

Keadilan Dasar-Dasar Filsafat Politik untuk Mewujudkan Kesejahteraan Sosial dalam Negara, Cet. II, Pustaka Pelajar, Yogyakarta.

Nasution, 1998, Metode Penelitian Naturalistik Kualitatif, Tarsito, Bandung.

Pranoto Iskandar, 2012, Hukum Hak Asasi Manusia Internasional: Sebuah Pengantar Kontekstual, IMR Press, Cianjur.
Stephen James,2007, Universal Human Rights : Origins and Developments, LFB Scholarly Publishing, New York

Terry Hutchinson, 2002, Researching and Writing in Law, Thomson Legal \& Regulatory Limited, Australia.

Aldo Meyolla Geraldino, Usia 14 tahun Kuliah di UGM, http:// ugm.ac.id/id/berita/10281-aldo. meyolla.geraldino.usia.14. tahun.kuliah.di.ugm, diunduh pada tanggal 15 Maret 2016

Deklarasi Universal Hak Asasi Manusia 1948.

International Covenant on Civil and Political Rights 1966.

International Covenant on Economic, Social and Cultural Rights 1966 Undang-Undang Nomor 20 Tahun 2003 tentang Sistem Pendidikan Nasional.

Peraturan Pemerintah Republik Indonesia Nomor 17 Tahun 2010 tentang Pengelolaan dan Penyelenggaraan Pendidikan.

Peraturan Bersama antara Menteri Pendidikan dan Kebudayan Republik Indonesia dan Mentri Agama Republik Indonesia Nomor NOMOR 2/VII/PB/2014, NOMOR7TAHUN2014 tentang Penerimaan Peserta Didik Baru pada Taman Kanak-Kanak/ Raudhatul AthFal/Bustanul Athfal dan Sekolah/Madrasah. 